\title{
The impact that the influenza A (H1N1) pandemic had on news reporting in the state of Paraná, Brazil
}

\author{
Sandra Mara Maciel-Lima \\ Professor, Centro Universitário de Curitiba. \\ Rua Chile, 1.678 \\ 80220-181 - Curitiba - PR - Brasil \\ ari.san.dra@hotmail.com \\ José Miguel Rasia \\ Professor, Universidade Federal do Paraná. \\ Rua General Carneiro, $460 / 9^{\circ}$ andar \\ 82060-000 - Curitiba - PR - Brasil \\ zecarasia@gmail.com
}

\section{Rodrigo Cechelero Bagatelli \\ Professor, Universidade Federal do Paraná. Av. Lothário Meissner, 632 80210-170 - Curitiba - PR - Brasil rodrigobagatelli@yahoo.com.br \\ Giseli Gontarski \\ Professor, Universidade do Contestado. Rua General Carneiro, 460/9 andar 82060-000 - Curitiba - PR - Brasil giseligontarski@yahoo.com.br \\ Máximo José D. Colares \\ Nurse, Universidade Federal do Paraná. Rua General Carneiro, 181 80060-900 - Curitiba - PR - Brasil \\ máximo_prime@yahoo.com.br}

Received for publication in April 2013.

Approved for publication in January 2014.

Translated by Derrick Guy Phillips.

http://dx.doi.org/10.1590/S0104-59702015000100016

MACIEL-LIMA, Sandra Mara et al. The impact that the influenza A (H1N1) pandemic had on news reporting in the state of Paraná, Brazil. História, Ciências, Saúde-Manguinhos, v.22, n.1, jan.-mar. 2015. Available at: http:// www.scielo.br/hcsm.

\section{Abstract}

This study aims to analyze how influenza A (H1N1) in 2009 was reported in the state of Paraná. A total of 189 articles were analyzed in two newspapers from Paraná. Pursuant to analysis, four themes were identified: the spread of the virus; the pandemic and fear; influenza in the health service; and influenza in public policies. By studying how influenza A was reported in the media, it was possible to see the social impact that the H1N1 pandemic represented for society, presenting challenges for public institutions and ordinary citizens, who sensed that they were in a high-risk group exposed to a potentially lethal virus. This disease radically changed the habits of a globalized community seeking to escape from vulnerability.

Keywords: influenza A (H1N1); pandemic; public health system; public health policies. 
$\mathrm{I}_{\mathrm{n}}^{\mathrm{n}}$ April 2009, society faced the impending threat of the influenza A virus, a new strain of influenza, originating in pigs, which had first been detected in Mexico earlier that year and had spread rapidly throughout the world (Bellei, Melchior, 2011). In the same month, and following reports of numerous cases of people infected in Mexico, the World Health Organization (WHO) declared the new flu virus a pandemic and requested that health authorities everywhere monitor all cases of flu and pneumonia.

From that time onwards, the world's media published reports about the disease, thereby fulfilling its role in alerting the public to possible dangers or a public health crisis (Medeiros, Massarani, 2011; González, Hoyos, Méndez, 2011), which could affect millions of people around the world. It gradually became clear that this new epidemic was the first new major disease in the field of viral infections in the twenty-first century, especially as it soon developed into a global epidemic. Notwithstanding the value of these alerts, the tone of the daily press reports also helped spread a sense of fear and alarm among the population in countries where there had been outbreaks of the virus. It was effectively a situation in which there was too much scaremongering and not enough information. In Brazil, the media released daily reports that were constantly updated, with details of the number of cases registered, victims hospitalized, the gravity of each case and subsequent deaths. According to Bertucci (2009, p.230), the reports that appeared in the press in 2009 "echoed the statements made by non-professionals and doctors in 1918, when the devastating Spanish flu or influenza pandemic decimated the planet."

Spanish flu was first registered on American soil during the second half of 1918, at the end of the First World War. In less than a month people were being struck down by this sudden and deadly virus; even so, researchers took some time to discover what it was and how such a widespread and lethal pandemic had first emerged (Silveira, 2008).

According to Patterson and Pyle (quoted in Silveira, 2008, p.31), epidemiological studies confirmed that Spanish influenza had appeared in the form of "three waves." The "Spring wave," was a mild form of influenza and appeared during the month of March in the midwestern region of the United States, before "spreading to Europe and reaching northern Africa, India, China and Australia in July." A second wave, in August, was confirmed as being a mutation of this highly lethal virus, and quickly spread around the world. At this stage, the flu virus had caught the attention of "public, scientific bodies and society in general." Finally, at the beginning of 1919, a much milder form of the flu epidemic appeared in a third wave.

In Brazil, Spanish flu began to cause concern within the government and among the population in general in September 1918, when Brazilians caught the disease in Africa and died: "These men were members of the Brazilian Medical Mission and soldiers of the national army, whose ships were anchored at Dakar (Senegal) and at Freetown (Sierra Leone) during the first week of September, before continuing on their journey to Europe at war" (Bertucci, 2009 , p.230). During the same period, news arrived that the ship Demerara, on its way from Europe, "had docked at the cities of Recife, Salvador and Rio de Janeiro with sick men aboard. At the end of September, reports began to circulate all over the country about people having caught influenza in port cities and, only a few days later, this virus claimed victims in the interior of the country as well" (Bertucci, 2009, p.230). 
Specialists have not yet reached a consensus about how many people were infected with influenza during the period from 1918-1919. However, Werner (quoted in Bertolli Filho, 2003, p.73-74) "suggests that nearly 600 million cases of flu had been reported" with nearly twenty million deaths worldwide. Little information exists about the total number of deaths from influenza in Brazil; however, "it is know that official figures registered 12,388 deaths from influenza in Rio de Janeiro with another 12,386 deaths in the whole state of São Paulo."

The outbreak of influenza that occurred in Brazil gave rise to several controversies. For example, even though the disease had already claimed hundreds of victims in Rio de Janeiro and Belo Horizonte, the Brazilian sanitary authorities claimed that the cases that had been confirmed were just a benign strain of flu and that no special measures were needed. According to Silveira (2008, p.252), there are at least five different reasons to explain why no specific actions were taken at the time to combat the disease: (a) (mis)information regarding the nature of the disease; (b) belief amongst the medical profession that the strain of influenza in the country was much milder than the one that had claimed Brazilian lives in Dakar; (c) the fact that this disease was characterized as an outbreak of common flu, of an exceptional nature, that represented no special threat; (d) the rapid spread of the disease amongst the population which, according to the medical handbooks of that time, indicated that it would be unjustifiable or useless to impose quarantine or to disinfect frontier areas; and, finally (e) that a policy of restriction and isolation would create discontent among economic groups.

In spite of these controversies, the medical authorities responsible for public health in other cities around the country decided to implement these same discredited measures: making it compulsory to notify all cases of the disease, to disinfect focal points of the virus and to isolate all victims. Even without detailed knowledge of the nature of the disease, "the authorities resorted to old practices imposed in cases of epidemic diseases: isolation and quarantine" (Silveira, 2008, p.252).

In 1918, there were still no vaccines or medication to cure flu or to provide immunization against influenza, only basic health recommendations under the heading "Advice to the People," such as: avoid crowds, do not visit other people, practice personal hygiene, etc., which were published repeatedly over several weeks in a number of newspapers. Similar concerns were shown in 2009, since "as was the case at the beginning of the twentieth century, doctors-researchers around the world had still not completely deciphered influenza (its control or effective prevention) and the measures to combat influenza A remind us very much of similar procedures used to fight the Spanish flu epidemic of 1918 " (Bertucci, 2009, p.231).

It should be said that addressing the 2009 (H1N1) flu epidemic using the same parameters as those used at the time of the Spanish flu epidemic of 1918, was short sighted to say the least. Even the way the press handled the matter did not seem to take into account the great advances that have been made in the sanitation conditions in present-day society. Indeed, the press treated the outbreak of influenza A (H1N1) as if it were comparable to the Spanish flu epidemic, failing to consider the different contexts in which each outbreak occurred. If, on the one hand, the deadly threats posed by influenza A (H1N1) were reported in the press, on the other hand the newspapers did little to explain these in the context of the technological developments that had been achieved in the field of contemporary biomedicine. 


\section{Method}

This study presents an analysis of how the outbreak of influenza A (H1N1) in 2009 was reported in the press in the state of Paraná, in Brazil. In order to do this, we carried out documentary research covering the period between May and September 2009 in two of the newspapers which have the largest circulation in the state: the Gazeta do Povo and the Tribuna do Povo. The first is the oldest and most traditional newspaper in the region, with the largest circulation and whose readers mainly represent the middle and elite classes in the state of Paraná. The second has a wide circulation among the lower-income and less-educated sectors of the population, and is seen as a popular tabloid and sensationalist newspaper. Reports on the flu epidemic in the Gazeta do Povo were printed in the "Vida e Cidadania" (Life \& Citizenship) supplement, under the sections "Health" and "Pandemic," with special emphasis given to details of influenza A in the whole state of Paraná. Reports printed in the Tribuna do Paraná, appeared in the "Planeta" (Planet) and "Tudo" (Everything) supplement, in a thematic section entitled "O papo é gripe suína," (Today's Chat is all about Swine Fever), and generally combined an update on Influenza A in Brazil and the rest of the world in the same report.

The 189 articles about the flu epidemic which were printed in both newspapers were treated using the content analysis method (Bardin, 1977), taking into consideration the wording of the headings and text of the articles. From this analysis, it was possible to establish four lines of approach: the spread of the virus; the pandemic and the fear that it caused; influenza in the health service; and influenza in public policies. In addition, research was also undertaken in international newspapers, in order to see what sort of press coverage was given to the flu epidemic by other countries during the same period.

\section{The global extension of the flu pandemic}

According to reports from the World Health Organization (WHO) (Table 1), over 343,000 cases of influenza A (H1N1) were confirmed in October 2009, with 4,108 deaths reported worldwide (Chile, 2009, p.11).

Table 1: Accumulated number of cases of influenza up to September 13, 2009

\begin{tabular}{l|r|r|}
\hline \multirow{2}{*}{ Region } & \multicolumn{2}{|c|}{ Accumulated number of cases up to September 13, 2009 } \\
\cline { 2 - 3 } & Cases & Deaths \\
\hline WHO Regional Office for Africa (Afro) & 8,352 & 42 \\
WHO Regional Office for the Americas & 137,147 & 3,020 \\
(Amro) & 12,008 & 74 \\
WHO Regional Office for the Eastern Mediterranean & & At least 176 \\
(Emro) & About 56,000 \\
WHO Regional Office for Europe (Euro) & 33,594 & 413 \\
WHO Regional Office for South-East Asia (Searo) & 96,197 & 383 \\
WHO Regional Office for the Western Pacific (WPRO) & 343,298 & 4,108 \\
\hline TOTAL & & \\
\hline
\end{tabular}

Source: Adapted from the World Health Organization Report, quoted in Chile (2009, p.11). 
The Pan American Health Organization (PAHO) reported that the highest number of confirmed cases and deaths in North America was registered during the last week of September 2009. In the United States and Canada, there was an increase in the number of consultations made for a virus similar to influenza A, and, in Canada two outbreaks of influenza were reported. This same report added that the number of confirmed cases in Central America peaked in July that year, before slowly petering out. Some countries in the Caribbean also suffered from outbreaks of flu during the same period (Chile, 2009).

According to figures shown in Table 1, it may be inferred that the highest number of cases were concentrated in the Americas, which showed a much higher death rate $(2.20 \%)$ than the average ratio in other regions. Europe and the Western Pacific presented the lowest number of cases and also the lowest percentage of deaths of those infected, $0.31 \%$ and $0.39 \%$ respectively. In Asia, the number of recorded deaths represented 1.22\% of those infected. It should also be noted that these figures relate to the number of confirmed cases reported to the health services in these regions. Since under-reporting, to a greater or lesser degree, was quite common in all of these regions, such figures are considered to be relative. In this respect, it is not possible to discuss the spread of the influenza A (H1N1) pandemic in 2009 and only refer to global figures for the virus, since little data exists to show the true extent of the problem.

Mexico was the country that suffered the greatest impact following the first outbreak of the influenza A (H1N1) virus. On April 17, 2009, the Mexican Secretariat of Health decreed "a state of alert," due to the gradual transmission of an acute form of pneumonia. On April 22, the influenza A (H1N1) virus was detected in exams collected. On April 24, the Mexican government used all means of communication to inform the public about infection prevention and control measures for respiratory hygiene, such as social distancing and community containment, namely closing down schools, restaurants and public places. The report issued by the Mexican Health Secretariat confirmed that 5,563 cases of influenza A had been identified, with 102 deaths, between March 1 and July 2, 2009 (González, Hoyos, Méndez, 2011).

In view of the situation, on April 25, 2009, the WHO declared "an international state of emergency," and on July 11 of the same year raised the alert level to phase 6, indicating that there was widespread transmission of the virus. According to Jiménez-Corona et al. (2012), in spite of initial fears, the spread of the influenza virus was less dramatic than at first expected.

In an attempt to alert the population about the risks of the influenza A (H1N1) outbreak, the media in Chile often ended up publicizing incorrect or misleading information about risk factors, high-risk groups, and the efficiency and safety of the influenza A (H1N1) virus vaccine (Jiménez-Corona et al., 2012; González, Hoyos, Méndez, 2011).

González, Hoyos and Méndez (2011, p.107) analyzed two newspapers from Mexico City with a wide circulation in the country - El Universal and La Jornada - and identified their use of metaphors to promote the content of these communiqués to their readers. These metaphors were used as a means of "penetrating the minds of the readers," and varied between informing, persuading, concealing, clarifying or increasing the comprehension of complex questions that were difficult for the general public to understand.

These authors identified several discursive metaphors used in a socio-cultural context that were "highly creative and included rich forms of expression to describe the impact of 
the epidemic" within the country (González, Hoyos and Méndez, 2011, p.128). For example, influenza A (H1N1) was described as: "a stigmatizing agent" (p.116), because of the way many rejected or even discriminated against the inhabitants of Mexico City as a result of the outbreak in the city; "an agent that is both paralyzing and onerous" (p.116), leading to the closure of commercial, productive and service establishments at a time when the economic situation in Mexico was extremely delicate; "an agent that is an accessory to poverty" (p.116), which was a metaphor to underline one of Mexico's main social problems as well as to highlight the fact that over one hundred people, mainly from the poorer section of the population, had already died from the virus in Mexico; "a political weapon" (p.116), because the outbreak of the virus occurred in the country at the time Mexico was much involved in preparing its political campaigns for the forthcoming federal elections and, in this environment, the government and the different political parties were keen to advance their campaigns amongst the people, by taking advantage of these health and sanitation emergencies; the virus was "a punishment" (p.116), as many people believed that the influenza A (H1N1) flu virus was a sign of Divine punishment because abortion had been legalized in Mexico City just over two years previously, among other metaphors (González, Hoyos, Méndez, 2011).

Lopes, Ruão and Marinho (2010) carried out a study of Portuguese newspapers that are widely circulated nationwide, namely the Expresso, Público and the Jornal de Notícias, with the aim of identifying the main sources of information used in their press coverage of the influenza A (H1N1) epidemic in the country. Based on an analysis of 655 articles related to the flu epidemic, it was seen that something of a media pandemic had occurred, "not even the number of deaths expected worldwide were mentioned, nor was an appeal ever made for keeping calm on a national level" (p.139). Instead, what really stood out were the declarations made by official sources, both from within the county and abroad. There was a "media pandemic that would have difficulty surviving once removed from the sphere of the media, but which, by activating sophisticated sources of information, managed to maintain a high media profile for a year" (p.141).

The authors conclude that:

the media offers essential communications channels in situations where there is a risk to public health; (2) health journalism, particularly in a high-risk situation, was seen to be heavily dependent on official and specialist sources when attempting to explain certain situations; (3) the official health bodies demonstrated a high level of professionalism when communicating high-risk situations; and (4) ordinary citizens represented the weakest link, since the public found itself at the mercy of this power struggle between journalists and official sources (Lopes, Ruão, Marinho, 2010, p.153).

\section{How influenza H1N1 was reported in the media in the state of Paraná}

According to the National Health Surveillance Secretariat (Secretaria..., 2010, p.1):

This influenza is a viral infection which affects principally the nose, throat, bronchi and, occasionally, the lungs. There are three known types of this influenza: A, B and C. These viruses are highly transmissible and can suffer mutations (transformation in their genetic structure), of which Type A is the most mutable of the three. In general, 
epidemics and pandemics (epidemics that occur in various countries) are associated with Type A virus.

This virus can be transmitted directly through secretions in the respiratory tract of an infected person when they speak, sneeze or cough, or indirectly through hand contact with contaminated surfaces or objects that, when touched, can transport the virus to the mouth, nose or eyes. The main symptoms of influenza are a sudden high fever, muscular pains, headache, a lack of well-being, a non-productive cough, coryza (runny nose) and rhinitis. This virus can cause complications in children, elderly people, or those with lung, metabolic, kidney diseases etc.; however, most people recover within one to two weeks, without the need for medical treatment. In the Southern Hemisphere, common influenza occurs with greater intensity during the colder months of the year (Secretaria..., 2010). According to the National Health Surveillance Secretariat (Secretaria..., 2010, p.2), "in Brazil the pandemic was divided into two distinct epidemiological and operational phases: (1) The containment phase ... and (2) the mitigation phase." In the containment phase, surveillance actions seek to reduce the spread of the virus in the country by implementing public health surveillance measures at seaports, airports and frontier areas, with the aim of identifying suspected cases of flu. This is necessary at this stage since cases of influenza are related to international travel or contact with those who have undertaken international journeys. At that point in time, there was no evidence that this was a case of sustained viral replication. During the mitigation phase, health surveillance measures were taken in an attempt to reduce the serious effects and incidence of deaths from this disease, by diagnosing and treating all those at risk.

The Electronic Epidemiological Bulletin (Boletim Eletrônico Epidemiológico) (Secretaria..., 2010, p.6, 9) stated that:

During the contention phase, of the 4,434 cases confirmed by laboratorial or epidemiological clinical criteria, 35\% $(1,556)$ presented a clinical diagnosis of Severe Acute Respiratory Syndrome (SARS), defined by fever, a cough and shortness of breath (Table 2). Of these, $14.5 \%(227 / 1,556)$ led to the death of the victims ... With regards to the epidemiological profile of confirmed cases, it was observed that the contention phase shows a predominance of male individuals. With an average age of between 20 and 29 years, they represent $29.3 \%$ of all registered cases. These data corroborate the profile of international travelers.

In the mitigation phase, there was an inversion in relation to gender, showing a predominance of cases involving females, who represented $57.2 \%$ of the total. There was no significant difference in relation to race/color. However, with regards to levels of education, there are noticeable changes depending on if the person had a primary school education. In this phase, it was noted that there was a higher percentage of cases involving pregnant women within the female reproductive age group. As regards age, it was observed that in $24.3 \%$ of the cases, the average age of the person was between 20 and 28 years.

Table 2 shows the distribution of cases by state up to the $33^{\text {rd }}$ Epidemiological Week, which ended on August 22, 2009. At the height of the epidemic, the state of Paraná had the second highest number of cases after São Paulo. 
In Paraná, $12.2 \%$ of the influenza cases evolved into Severe Acute Respiratory Syndrome (SARS). Compared to cases of seasonal flu, in the same week 181 cases of influenza were notified and confirmed, of which $1.5 \%$ evolved into SARS.

During the same period, in the southern states of Brazil, 461 cases of influenza were confirmed in Rio Grande do Sul, with a further 114 in Santa Catarina. Of these, 6.4\% of the cases in Rio Grande do Sul and 5.6\% of those in Santa Catarina evolved into SARS. There were 55 and 44 cases, respectively, of seasonal flu, of which $2 \%$ and $2.2 \%$ evolved into SARS.

\begin{tabular}{|c|c|}
\hline Units of the Federation & H1N1 \\
\hline São Paulo & 2,482 \\
\hline Paraná & 1,444 \\
\hline Rio Grande do Sul & 461 \\
\hline Rio de Janeiro & 316 \\
\hline Santa Catarina & 114 \\
\hline Federal District & 78 \\
\hline Pará & 69 \\
\hline Minas Gerais & 67 \\
\hline Pernambuco & 26 \\
\hline Ceará & 21 \\
\hline Amazonas & 18 \\
\hline Bahia & 17 \\
\hline Mato Grosso do Sul & 14 \\
\hline Goiás & 13 \\
\hline Rio Grande do Norte & 11 \\
\hline Maranhão & 8 \\
\hline Acre & 8 \\
\hline Roraima & 7 \\
\hline Alagoas & 6 \\
\hline Piauí & 5 \\
\hline Amapá & 2 \\
\hline Rondônia & 1 \\
\hline Sergipe & - \\
\hline Tocantins & - \\
\hline TOTAL & 5,206 \\
\hline
\end{tabular}

In the case of deaths caused by influenza A (H1N1) (Table 3), the state of Paraná is again the state which recorded the second highest number of deaths, while São Paulo was in first place during Epidemiological Week 32, which ended on August 15, 2009. The states of São Paulo and Paraná accounted for 232 of the 368 deaths that occurred during the week in question. São Paulo registered $41 \%$ and Paraná registered $22 \%$ of the total number of deaths during this period.

In Brazil, both during the contention and mitigation phases, one of the measures taken by the Ministry of Health was to organize a massive communications campaign using all media channels, including social networks to reach younger members of the public. In addition, they issued daily bulletins about the epidemiological situation (during the contention phase) 
and later organized similar updates every fifteen days (during the mitigation phase). The aim was to provide greater visibility about the measures adopted by the Brazilian government to deal with the epidemic, so as to reassure the general public that proper methods were being used to control the situation, and thereby avoid a sense of panic. The Ministry of Health used various channels, including TV, radio and printed material, to provide information about the prevention, signs and symptoms of the disease (Secretaria..., 2010).

Table 3: Distribution of deaths from influenza H1N1 $32^{\text {nd }}$ Epidemiological Week, which ended on August 15, 2009

\begin{tabular}{|l|r|c|}
\hline Units of the Federation & Cases & Percentage \% \\
\hline São Paulo & 151 & 41 \\
Paraná & 81 & 22 \\
Rio Grande do Sul & 68 & 18.5 \\
Rio de Janeiro & 45 & 12.2 \\
Santa Catarina & 10 & 2.7 \\
Minas Gerais & 7 & 1.9 \\
Paraíba & 2 & 0.5 \\
Rondônia & 1 & 0.3 \\
Mato Grosso do Sul & 1 & 0.3 \\
Federal District & 1 & 0.3 \\
Bahia & 1 & 0.3 \\
\hline BRAZIL & 368 & 100 \\
\hline
\end{tabular}

Source: Information System for Notifiable Diseases/National Health Surveillance Agency (Secretaria..., ago. 2009).

In order to better understand the media's position in Paraná and elsewhere in relation to the flu outbreak, consideration should first be given to the way the media interprets official health bulletins. Their lack of understanding about how to read and interpret epidemiological data or to understand the standards used by health services to calculate the extent and gravity of the flu outbreak meant that the epidemic ended up being transformed into something far more serious and alarming than it actually was.

By analyzing the news reports printed in the Gazeta do Povo and Tribuna do Paraná newspapers during the period between May and September, 2009, it is possible to see that these are based on four main themes: the spread of the virus; the pandemic and the fear that it caused; flu in the health services; and the inclusion of flu in public policies. The details are presented as follows.

\section{The spread of the virus}

On September 27, 1918, the São Paulo newspaper, O Combate announced, in explosive terms: "Spanish flu has already reached Brazil" (Bertucci-Martins, 2003, p.107). It is not easy to avoid a sense of panic when reading headlines such as these. In much the same way, in 2009, the Brazilian people learned that influenza A had reached Brazil via newspaper reports.

"More suspected cases, minister says the arrival of the virus is now inevitable (Tribuna..., 2 maio 2009, p.5).

"Flu reaches South America" (Tribuna..., 4 maio 2009, p.8).

"Brazil confirms the first person infected in the country" (Gazeta..., 9 maio 2009, p.4). 


\begin{abstract}
"Paraná confirms first case of influenza A (H1N1) - Number of infected persons more than doubles in a week. The Secretary of Health for Rio is also suspected of having the disease" (Gazeta..., 20 jun. 2009, p.5).
\end{abstract}

"The flu virus is gathering strength" (Tribuna..., 12 maio 2009, p.7).

The first suspected case of influenza A appeared in Curitiba on May 6, 2009, while the first case in the state of Paraná was confirmed on June 20, 2009. By this date, 131 cases had been reported in Brazil. At that time, confirmation was made by means of laboratory tests. It is important to bear this in mind, since the first confirmed case was not necessarily the first case of influenza A that occurred in the state, since there could have been other cases that were not notified and where the person infected did not undergo the necessary biochemical tests.

Until then: "There has been no registered case of influenza A (H1N1) being transmitted within the state of Paraná itself - all confirmed cases relate to people who were contaminated while they were travelling abroad" (Gazeta..., 23 jun. 2009, p.9).

On June 25, the first case was recorded of someone being contaminated in Brazil; until that time, all reported cases had been linked to patients who had travelled to Brazil from abroad. This is when the sustained replication of the virus first began in the country. "PR (Paraná) has registered two cases of people who were contaminated in the country" (Gazeta..., 25 jun. 2009, p.9).

The virus quickly spreads across the state of Paraná; on July 8, 2009, the newspapers were already reporting that: "in Paraná, internal contamination is above the average" and " $29 \%$ of all cases of swine flu in Paraná have been transmitted within the state. The national average is 23.4\%" (Gazeta..., 8 jul. 2009, p.7).

One of the factors that contributed to the rapid spread of the virus within the state was the very cold winter of 2009, with very low temperatures and a good deal of rain. According to data from the Meteorological System of Paraná (SIMEPAR), the winter of 2009 was one of the coldest recorded in recent years.

In view of the fact that the Minister of Health had declared that the flu A virus was circulating freely in the country (Gazeta..., 19 jul. 2009, p.9), together with reports that 51 cases of swine flu had already been confirmed in the state of Paraná (Tribuna..., 15 jul. 2009, p.4), schools decided to delay the start of the new semester so as to prevent the transmission of the disease. The local newspapers suggested methods to help prevent the spread of the flu virus: practice personal hygiene, isolation, avoid enclosed spaces and maintain domestic environments well aired and with as much access to sunlight as possible. Every day, the newspapers proposed and repeated recommendations for personal hygiene and other ways to avoid flu contamination. This resulted in a rush to buy products, such as alcohol gel, which soon disappeared from the shelves and had its price increased by as much as $900 \%$ by the beginning of August. On July 22, 2009, the newspapers reported the first death in the State:

"First person dies from influenza in Paraná" (Gazeta..., 22 jul. 2009, p.5).

"First death from flu in PR" (Tribuna..., 22 jul. 2009, p.4).

At this stage, the State of Paraná changes all procedures for the treatment of cases of influenza A (H1N1). One of the measures adopted as from June 24, 2009 is to centralize the 
treatment of those patients who were in a serious condition or whose lives were at risk, and who needed to be hospitalized, in the emergency departments at the Hospital de Clinicas at the Federal University of Paraná (UFPR). The aim of this measure is to establish a suitable structure in the event that large numbers of cases require hospitalization.

The death toll from influenza A (H1N1) in the state of Paraná peaked at the beginning of August (with 13 deaths on May 5, 2009), and there are signs that these numbers begin to level out as from August 20, 2009.

It is also interesting to note that, up until August 2, 2009, details of the number of cases of influenza registered in Paraná appeared in the newspapers under large headlines and written in bold letters, but after that date this type of information is only shown divided by region, in small graphs and in small print, at the side of the article, as can be seen particularly in reports published by the Gazeta do Povo. There was also the question of the discrepancies in the numbers given out; for example, on September 14 it was announced that there had been 264 deaths from influenza in the state of Paraná, with a further 1,968 confirmed cases of flu; however, on September 26, it was revealed that there had been 245 deaths in Paraná, with over ten thousand further confirmed cases of flu. One of the possible reasons for this discrepancy in numbers may be the fact that it took time to carry out the necessary laboratory tests - which in that state are always processed faster in August - to confirm cases of the influenza A (H1N1) virus, so that the numbers varied a good deal. At that time, it was still only possible to count the number of registered cases after these had been confirmed through laboratory tests. However, bearing in mind that countless cases had not been notified or had never been investigated through the means of specific examinations, these numbers probably do not reflect the true reality of the situation.

\section{The pandemic and the fear that it caused}

With regards to influenza H1N1, it was two months after the first cases were reported in Mexico, that the virus multiplied and cases began to appear in Brazil, particularly in the state of Paraná. This feels like a long time for those individuals suffering from the disease, who have to deal with the delays in seeing the results of their treatment and the threat that this virus represents to society, but perhaps too short a time for the necessary sanitary measures to be put into place to protect and ensure the well-being of the population. Although influenza H1N1 is transmitted in the same way as the common cold, the probable mortality rate for this disease was unknown to medicine at the beginning of the pandemic, although thought to be higher than figures for the common cold. The fact that no treatment protocol then existed created greater uncertainty, not only among the population, but also in the medical profession itself. The wide-ranging symptoms, which at first appear to only require primary health care, generate distress. The situation is made worse because no-one really knows who is at most risk, since everyone is considered to be vulnerable to the disease.

According to Winocur (2009), we live in an era of uncertainty and risk. This means that people have to be aware of everything that is around them. In the case of influenza A, if there is a visible lack of response to this type of situation, it just means that the population and the medical services are left in a constant state of alarm. Every time a new fatality from the flu is reported, the image of death, the termination of life, is reactivated in the public's imagination. 
Giddens, Beck and Lash (1997) draw our attention to risk as being a structural component of contemporary society. In situations of crisis, like the outbreak of a previously unknown disease, controlling the threat that this represents goes beyond present comprehension, both individual and scientific.

A pandemic and fear of influenza changes the habits of the population which has to adopt new practices of hygiene and patterns of behavior, which include expectant mothers having to change their daily routines; cancelling trips; closing certain establishments, mainly schools; suspending collective festivities; and distributing surgical masks to hospital employees and visitors: "Hospital under quarantine due to suspect death" (Gazeta..., 20 jul. 2009, p.4).

Patients who arrived at one hospital located in the Metropolitan Region of Curitiba checked to see if staff members and ancillary hospital staff were duly protected by surgical masks, due to the possibility of a case of influenza among the patients at the hospital. Their families decided not to admit them to that hospital and go elsewhere: "We still do not know where we will take them, but we are afraid to stay here" (Gazeta..., 20 jul. 2009, p.4).

Concerns for pregnant women increase significantly, due to their immunological conditions and possible complications for the foetus and gestation development: "We are particularly concerned about pregnant women: premature births and complications can be caused by influenza A, which has already claimed the lives of three pregnant women" (Gazeta..., 31 jul. 2009, p.6). They receive medication at the first sign of flu symptoms, together with older people, diabetics, heart patients, HIV positives and children under the age of five.

"39-week pregnant woman says, ... I only leave home to attend medical appointments or in cases of extreme urgency. 'I stay at home all day,' she says" (Gazeta..., 31 jul. 2009, p.6).

"Risk factor increases death rate: pregnant women, hypertensive and other heart patients have a 3.5 greater chance of dying than other seriously-ill patients" (Gazeta..., 1 ago. 2009, p.6).

Pregnant women also strictly adhere to the rule to avoid enclosed spaces, as well as taking early maternity leave.

The general public is worried that the required medication will not be available if they catch influenza A (H1N1); however, the Health Secretariat states that there will be no shortage of this medication. In spite of their guarantee, the newspapers continue to assert that the population will face difficulties in getting these drugs.

"The saga in search of Tamiflu continues" (Gazeta..., 6 ago. 2009, p.4).

"Research figures show that $67 \%$ of the city's population fear that they will not be given Tamiflu, if they catch influenza A" (Gazeta..., 16 ago. 2009, p.4).

The difficulties mentioned above, were clarified by the statement of one father, published in the Gazeta do Povo, who spent 17 hours trying to get hold of Tamiflu for his 14-month-old son: "It gives you a terrible feeling of impotency. I feel as if I have taken ten days over this. I went through hours of sheer agony. I have never seen such a lack of information, nobody knows what to do; no one can tell you if and when this medication will arrive. Just imagine those who have no information?" (Gazeta..., 6 ago. 2009, p.4). 
The fact that this medication is so difficult to find only reinforces the climate of fear and uncertainty that the population feels when confronted by a rapidly-evolving and extremely deadly disease, about which very little is known at that time. In view of the fear caused by influenza A (H1N1), the president of the Town Hall in the city of Curitiba announced special measures to prevent the spread of the disease (Tribuna..., 4 ago. 2009, p.2), such as: changing the hours of the plenary sessions, in-house working hours and suspending programmed events. Some municipalities also resolved that some commercial establishments should not be allowed to open for business, especially those with enclosed spaces and where large groups of people gather. People also had to use surgical masks on the buses, at local fairs, hospitals and health units. Catholic churches, concerned about the spread of the disease and keen to help by adopting preventative measures, also removed holy water from the entrance of their churches, keeping their windows and doors open and asking that the traditional embrace and handshakes between members of the congregation be replaced by a few moments of silence. Schools delayed the return to classes after the July holiday break, to avoid groups of children gathering together and also to give teachers time to receive training in how to recognize flu symptoms among their pupils." Fear returns to the classrooms - the beginning of term is delayed and the church cuts off holy water" (Tribuna..., 26 jul. 2009, p.2). People going to the bank had to wait outside the building to avoid overcrowding inside: "Flu hampers customer service at banks" (Tribuna..., 11 ago. 2009, p.5).

To avoid panic, the government issued various statements denying the rumors that had been posted on e-mail and which helped foment despair and fear among the population. Rumors were circulated, including those which called into question the official statements being issued, claiming that the number of reported deaths was well below the true figures.

As the flu spread, with a growing number of cases in the state of Paraná and in the country as a whole, the population felt increasingly at the mercy of the pandemic and its effects. Since the newspapers were publishing daily updates on the spread of the virus, with the same sort of coverage being given, almost in real-time, by TV channels, via the radio and the Internet, it was not surprising that the public began to feel equally uncertain about each coming moment, when it seemed everyone would become contaminated by the flu virus. Schools had cancelled classes, cinemas were empty, everyone was avoiding shopping malls and public transport was only used by those who had no alternative means of transport. Even in the cold and the rain, buses kept their windows open. Anyone caught coughing or sneezing in public without the protection of a handkerchief was instinctively censored, and the person who coughed or sneezed felt guilty about the risk they might have imposed on others. An awareness of the risks involved and a fear of influenza A, meant that each person sought to protect themselves as much as possible while also trying to protect others, doing all that they could to avoid making others feel uncomfortable if their presence could not be avoided.

\section{The flu epidemic and the health services}

The numbers of reported cases of influenza A (H1N1) rapidly increased in the state of Paraná between the months of May and August, and, according to the State Secretary of Health:

Many of those who present flu and positive epidemiological symptoms are seeking the Health Service, which to a certain extent makes it easier to monitor the health 
situation and to identify in advance if sustained transmission of the virus has occurred (Gazeta..., 27 jun. 2009, p.4).

In view of the great number of suspected flu cases, the state of Paraná makes a request to the Ministry of Health for the Central State Laboratory (Lacen), located in São José dos Pinhais, to carry out tests to confirm cases of this new flu virus (Gazeta..., 2 jul. 2009, p.7). The authorization of the Ministry of Health, with due training of Lacen technicians by Fiocruz, already reduces the waiting time for test results in the state by the end of June. "Greater speed in providing test results will help us map the circulation of Influenza A ... These tests help us map the way this virus is circulating, said the secretary of Health" (Gazeta..., 18 jul. 2009, p.4).

In the metropolitan district, the Pinhais Hospital and Maternity Ward were closed at the end of July so that the building could be disinfected, and the four members of staff who had contact with an infected patient were removed from the premises; this, because "a 24-yearold man may have been the first fatal victim of Influenza A (H1N1), also known as swine flu, in the region of Curitiba" (Gazeta..., 18 jul. 2009, p.4).

When the hospital re-opens, "employees working on reception will wear surgical masks until the results of the tests are received" (Gazeta..., 18 de jul. 2009, p.4). And the newspapers announced in bold letters:

"Long waiting times to receive treatment."

"In Curitiba, people with flu-like symptom wait up to 7 hours in line at the health post. But there is no risk of contamination" (Gazeta..., 23 jul. 2009, p.4).

The state secretary of health acknowledges that, with the increase in flu cases within the state of Paraná, there may be longer delays at health posts, possibly because the health service is not equipped to handle the growing demand caused by the flu outbreak. In addition, since lay persons find it difficult to tell the difference between influenza A and common flu symptoms, more people will be seeking help from their local health services. Added to this, the lines at the health posts will increase because, if they need Tamiflu, this medication is only being prescribed by doctors within the public health system. "It may be that waiting times will be longer here and there, since we cannot guarantee this 100\%, he admitted" (Gazeta..., 23 jul. 2009, p.4). Nevertheless, if, after screening, the patient is shown to have flu-like symptoms, staff at health units have been instructed to provide them with a surgical mask and send them to hospital, after first notifying the hospital in question.

In August, with the aim of providing better overall health care, doctors in Paraná demand that the Ministry of Health offer Tamiflu to all patients that show flu-like symptoms, and also complain that they have not been given the right to prescribe this medication, since prescriptions can only be made by doctors working within the public health system. A few days later, the newspapers report that the protocol for the prescription of Tamiflu will be altered by the Ministry of Health and, in special cases, doctors will be able to use this medication for patients seeking treatment via health plans or at private practices. However, this measure does not produce the expected results, since the drug is still scarce and is only being distributed by state and municipal health agencies. "In Curitiba, the town hall accepts a 
doctor's prescription even for people outside the risk group. According to the health secretary, prescriptions demand responsibility" (Gazeta..., 7 jul. 2012, p.5).

As the situation worsens, the increase in cases of influenza A prompt doctors in Paraná to organize themselves in a group to demand that Tamiflu be given to all patients with symptoms of the virus, even for those who seek medical help outside the public health system. The reluctance of the WHO to liberate the use of Tamiflu is largely due to their concerns that the virus will develop resistance to the medication, as well as by fears that stocks will be insufficient to treat the most serious cases, if contamination intensifies.

Finally, in August 2009, the WHO releases the following statement: "Since the benefits of oseltamivir (the main active ingredient of Tamiflu) are greater when given during the first 48 hours, doctors should begin this treatment immediately, and not wait for laboratory test results" (Gazeta..., 7 ago. 2012, p.5).

The articles systematically published by the newspapers about the movement set up by medical bodies and about the public's fears with regard to the flu epidemic, could well have influenced the WHO to decide to change its protocol on more than one occasion with regards to Tamiflu prescriptions, finally making it possible to prescribe this medication outside a public health service environment and to commercialize this product through pharmacies. However, the WHO recommends that Tamiflu should continue to be sold under medical supervision (Gazeta..., 1 ago. 2009, p.4).

\section{Influenza's place in public policies}

With the confirmation of the first endemic contamination in Brazil, the Ministry of Health declared that only four hospitals in Paraná would be able to receive infected patients: two in Curitiba (Hospital de Clínicas, of the Federal University of Paraná - UFPR and the Hospital do Trabalhador), another located in Londrina (the University Hospital) and one in Foz do Iguaçu (Ministro Costa Cavalcanti Hospital). The coordinator of the National Health Surveillance Agency in Londrina explains that: "We have to follow a special protocol to receive infected patients or those suspected of having contracted the virus ... Filtered air and respiratory isolation must be provided" (Gazeta..., 5 maio 2009, p.4).

Of the hospitals authorized to admit such patients, two were located in the southern region of the State (Curitiba), one in the north (Londrina) and the other in the southeast (Foz do Iguaçu). People living in smaller towns and areas far from these city centers had difficulty in getting to these hospitals. The norms established by the government meant that only a very limited number of hospital beds could be offered to seriously sick patients. In addition, members of the population were also forced to incur high costs to travel to these centers for treatment, which only increased the risk of dying from the virus.

As regards the population living in small towns in the interior of the state, they were in a far more serious situation compared to those living in larger cities, such as Curitiba, Londrina, Maringá and Foz do Iguaçu. In addition to the distances involved in trying to reach cities with accredited hospitals able to admit infected persons, the smaller towns did not have the means to offer adequate treatment for the most severe cases.

In May, technicians from the Secretary of Health carried out an inspection at the airport, the Ministro Costa Cavalcanti Hospital in Foz do Iguaçu, and the Itaipu hydroelectric plant, 
since these were all located in frontier areas. This was a necessary measure due to the large flux of foreign tourists going through the area; at this time, the sustained replication of the influenza A virus had still not occurred in Brazil.

\footnotetext{
"Special controls may be put in place along the highways" (Gazeta..., 14 maio 2009, p.5).

"Surveillance along the triple frontiers. The Army and Highway Patrol will distribute information and monitor the area" (Tribuna..., 9 jul. 2009, p.4).
}

At the beginning of June, the Ministry of Health recommends that the population cancel all planned journeys to destinations that have shown the highest incidence of cases. At airports, passengers are asked to fill out a Travelers' Health Declaration, and at bus and railway stations posters are put up giving details of the flu outbreak, its symptoms and preventative measures.

In July, the Ministry of Health increases the number of accredited hospitals which can treat influenza A cases in the Southern and South-eastern regions of the state. The state expands its structure, which now uses even the private health network. By including more hospitals in the health service network, more hospital beds become available in the smaller towns; however, the situation remains critical, due to the lack of available beds in intensive care units for the most severe cases.

With the increase in the number of cases, the public health system's main priority became the swift and effective detection and treatment of severe cases so as to avoid deaths from the virus. At the end of July, the government of Paraná announced that tests would be carried on all patients who presented flu-like symptoms, even those with no links abroad. The change announced by the Secretariat of Health was an admission, at that time, that the virus was now circulating freely within the state of Paraná. "From this moment onward the flu epidemic has become, not only a public health problem, but also a burden on public funds" (Gazeta..., 9 ago. 2009, p.4).

In August, the public health network was already treating 1,500 patients a day for suspected influenza A. Influenza A (H1N1) changed hospital routines, which cost the government of Paraná 19 million Brazilian reais. The cost to treat the 1,500 cases of influenza A does not, of course, translate only into monetary values, but also in the time and effort it took to reorganize the whole public and private health systems and especially the hospitals. As a whole, the system had to postpone a series of non-urgent procedures, such as elective surgeries and consultations at outpatient health clinics, where members of the public might be at some risk of contamination. At the Hospital de Clínicas, at the UFPR, all out-patient services were cancelled, and many members of staff had to be sent home and placed in quarantine, because they had had contact with infected patients or because they themselves were suspected of having contracted influenza A.

\section{Final considerations}

In spite of current scientific and technological knowledge, the influenza A (H1N1) epidemic of 2009 presented a special challenge for doctors and researchers all over the world as they attempted to find ways to control and effectively prevent the spread of the virus. 
The issues raised by Silveira (2008, p.252-253) regarding the lack of specific measures used to tackle Spanish flu, did not appear to be that evident during the more recent period researched. The organization of detailed information about the causative agent, the way medical data was homogenized by official health service institutions, providing guidance about which rules of conduct to follow, an understanding of the effectiveness of the preventative measures taken, and a better organized health system than at the time of the Spanish flu, give one the impression that there had been a marked improvement in the way this latest pandemic was dealt with. However, in this study, we were able to observe that these measures were not that effective in controlling people's fears in relation to the epidemic. Fears about the risk of the flu virus were clearly shown in a variety of everyday situations, which changed patterns of social behavior and permeated people's daily lives.

The first articles that were published in the press in Paraná gave great emphasis to the number of confirmed cases of flu around the world and in Brazil, and registered the first confirmed case in Paraná on June 20, 2009. On that day, 131 cases had been notified in the whole of Brazil. Following an increase in the number of confirmed cases, the newspapers began to print advice about how to prevent the spread of the epidemic: by providing tips on personal hygiene, isolation, avoiding enclosed spaces and maintaining home environments well-aired and with as much access to sunlight as possible. Every day, the newspapers printed and repeated advice on hygiene and the precautions needed to avoid catching the flu.

Although there were discrepancies in relation to the actual number of cases reported, the population still feared the disease. The pandemic and fear of the flu changed the routines of urban life. Surgical masks were distributed to hospital staff and visitors alike, as well as to those who worked with the public in various sectors of the economy. The fact that the risk of dying was higher for those belonging to an economically active sector of society (young people), as well as those at a stage in life when death is less expected (infants and pregnant women), may well have been contributing factors that only helped increase such fears.

The social determinants during that period contributed towards creating an unusual image of a high-risk group. At the beginning, the pandemic affected the wealthiest classes, since they were the only ones who had the means to make frequent trips abroad. However, it is noteworthy that this same purchasing power did not enable this same group to have access to the necessary drug (Tamiflu), since both its prescription and distribution were, initially at least, controlled by the State in the form of the Unified Health System (SUS) and the National Health Surveillance Agency. From this, it is possible to infer that it was due to this political arrangement that the principles of universal and equal rights, which are fundamental elements of the Brazilian health service, were thereby established and helped to guarantee fair public access to healthcare.

However, it was also evident that this access was somewhat precarious. This might be because of the high number of people seeking treatment (which is expected in the case of a pandemic of this kind, when initial symptoms are similar to those of a common cold, and especially when this occurs during a season of the year which is usually propitious for these types of ailments); or because of the fact that the whole health system apparatus was ill-prepared to cope with the demand for medical attention at all levels. The involvement 
of the private health sector became necessary to help tackle the pandemic, which just reflected the deficiencies that existed in the SUS.

The number of deaths in Paraná reached its peak at the beginning of August, and the virus began to stabilize as from the end of the same month. As the number of cases increased, the public health system's priority was to diagnose and treat severe cases of flu as quickly as possible so as to avoid deaths. Meanwhile, the population feared there would not be sufficient medication to treat them in the event they caught the flu.

In August 2009, the Ministry of Health announced that 95\% of those who had contracted the disease had been cured. Alarming reports about the epidemic had started to appear in the press at the beginning of May, but these began to level out at the end of September, which showed how the pandemic evolved during that year.

Finally, we were able to document, through this research study, the social impact that the H1N1flu pandemic represented for society in general at that time, and which challenged those institutions that are responsible for the health care of ordinary citizens. The latter sensed they were at high-risk from a disease that the media was publicizing as being potentially lethal, and which prompted immediate changes in the customs and habits of a whole community, in an effort to escape the threat of this deadly disease.

\section{REFERENCES}

BARDIN, Laurence.

Análise de conteúdo. Lisboa: Edições 70. 1977.

BELLEI, Nancy; MELCHIOR, Thaís Boim. H1N1: pandemia e perspectiva atual. Jornal Brasileiro de Patologia e Medicina Laboratorial, v.47, n.6, p.611-617. 2011.

BERTOLLI FILHO, Cláudio.

A gripe espanhola em São Paulo, 1918: epidemia e sociedade. São Paulo: Paz e Terra. 2003.

BERTUCCI, Liane Maria.

Gripe A, uma nova "espanhola"? Revista da Associação Médica Brasileira, v.55, n.3, p.230-231. 2009.

BERTUCCI-MARTINS, Liane Maria.

"Conselhos ao povo": educação contra a influenza de 1918. Caderno Cedes, v.23, n.59, p.103-117. Disponível em: http://www.cedes. unicamp.br. Acesso em: 20 jul. 2012. 2003.

CHILE.

Ministerio de Salud de Chile. Influenza Pandémica (H1N1) 2009. Disponível em: http://www.minsal. gob.cl/portal/url/item/769b3df25c5930dee040010 11f0160b4.pdf. Acesso em: 16 set. 2013. 2009.

GAZETA...

Gazeta do Povo, Curitiba. 5 maio 2009-7 ago. 2009.

GIDDENS, Anthony; BECK, Ulrich; LASH, Scott. Modernização reflexiva. São Paulo: Unesp. 1997.
GONZÁLEZ, Gabriela Del Carmen; HOYOS, José Ramiro Caballero; MÉNDEZ, Maria Guadalupe Chávez.

Las metáforas de la influenza humana A (H1N1) em México: el escenario nacional al descubierto. Una aproximación através de la prensa mexicana. Comunicación y Sociedade, n.16, p.105132. Disponível em: http://www.scielo.org.mx/ scielo.php?script=sci_arttext\&pid=S0188-252X20 $11000200005 \& \operatorname{lng}=$ es\&nrm=iso. 2011.

JIMÉNEZ-CORONA, Maria Eugênia et al. Conocimientos, actitudes y prácticas sobre la influenza A(H1N1) 2009 y la vacunación contra influenza pandémica: resultados de una encuesta poblacional. Salud Pública de México, v.54, p.607-615. Disponível em: http:// www.scielosp.org/scielo.php?pid=S003636342012000600009\&script=sci_arttext. Acesso em: 17 set. 2013. 2012.

LOPES, Felisbela; RUÃO, Teresa; MARINHO, Sandra.

Gripe A na Imprensa Portuguesa: uma doença em notícia através de uma organizada estratégia de comunicação. Observatorio (OBS*) Journal, v.4, n.4, p.139-156. Disponível em: http://obs. obercom.pt/index.php/obs/article/view/442/398. Acesso em: 18 set. 2013. 2010.

MEDEIROS, Flávia Natercia da Silva; MASSARANI, Luisa.

A cobertura da gripe A (H1N1) 2009 pelo 
Fantástico. Intercom - Revista Brasileira de Ciências da Comunicação, v.34, n.1, p.41-59. 2011.

SECRETARIA...

Secretaria de Vigilância em Saúde. Influenza pandêmica (H1N1) 2009 - análise da situação epidemiológica e da resposta no ano de 2009. Boletim Eletrônico Epidemiológico, v.10, n.1, p.121. Disponível em: http://portal.saude.gov. br/portal/arquivos/pdf/boletim_eletronico influenza_25_03.pdf. Acesso em: 15 ago. 2012. 2010.

SECRETARIA...

Secretaria de Vigilância em Saúde. Informe Epidemiológico Influenza H1N1, n.6. Disponível em: http://portal.saude.gov.br/portal/arquivos/ pdf/informe_influenza_se_33_25_08_2009.pdf. Acesso em: 5 out. 2013. ago. 2009.

SILVEIRA, Anny Jakeline Torres.

A influenza espanhola e a cidade planejada: Belo Horizonte, 1918. Belo Horizonte: Argvmentvm; Fapemig; Capes. 2008.

TRIBUNA...

Tribuna do Paraná, Curitiba. 2 maio 2009-11 ago. 2009.

WINOCUR, Rosalia.

Robinson Crusoé ya tiene celular. México: Siglo XXI. 2009. 